\title{
FEATURES OF KIDNEY DAMAGE IN HIV-INFECTED
}

\author{
Moskalyuk V.D. https://orcid.org/0000-0002-4104-8153 \\ Andrushchak M.O. https://orcid.org/0000-0002-79008674 \\ Sokolenko M.O. https://orcid.org/0000-0002-7150-7146 \\ Balanyuk I.V. https://orcid.org/0000-0002-3258-9791 \\ Boyko Y.I. https://orcid.org/0000-0001-6542-6844
}

Bukovynian State Medical University, Chernivtsi, Ukraine

margaritaassistent@gmail.com

\begin{abstract}
Relevance. In HIV-infected patients, renal disease, which is characterized by severe clinical manifestations, can significantly affect the prognosis of life. Given the growing number of HIV-infected people in the world and the increase in the life expectancy of such patients, an increase in the number of HIV-infected people in need of expensive renal replacement therapy, as well as kidney transplantation, should be expected. But the question of the nature of kidney damage in HIV infection in Ukraine is still insufficiently covered.

The objective of the work is to establish the clinical and laboratory features of kidney damage in HIV infection.

Materials and methods. 292 patients with HIV were examined. Screening for markers of kidney damage (albuminuria/proteinuria) was performed by test systems (using urine strips). The results obtained with the help of test strips were considered as indicative. In the presence of $\geq 1+$ proteinuria in the screening test, which corresponded to a gradation of $30 \mathrm{mg} / 1$, repeated urine analyzes were performed with quantitative determination of protein on a spectrophotometer, separated in time from 3 days to one week. The functional state of the kidneys was assessed by an integrated indicator that characterizes the degree of preservation/loss of mass of active nephrons. The criterion for renal impairment was a decrease in glomerular filtration rate (GFR) $<60 \mathrm{ml} / \mathrm{min}$ by $1.73 \mathrm{~m} 2$. Chronic kidney disease was diagnosed when proteinuria or proteinuria was detected in combination with a decrease in GFR for 3 months or more.
\end{abstract}

Results. Based on the main markers of renal damage (persistent proteinuria (PU) and glomerular filtration rate $<60 \mathrm{ml} / \mathrm{min} / 1.73 \mathrm{~m} 2$ ), 48 people were diagnosed with chronic kidney disease, which was often accompanied by dysfunction of these organs. Based on the analysis of complaints, anamnestic data and clinical symptoms of kidney damage, patients were divided into 2 groups. The first group (n $=31$, or $64.6 \%)$ - patients with tubulointerstitial, the second group $(n=17$, or $35.4 \%)$ - patients with glomerular diseases. Increased PU levels are accompanied by significantly significant renal impairment and more frequent combination with hypertension and hematuria in the absence of significant differences in the frequency of opportunistic diseases.

Conclusions. In HIV-infected kidney damage is most often characterized by their tubulointerstitial lesions. At the same time, glomerular kidney damage, which is much less common, is accompanied by significantly higher levels of HIV RNA.

Key words: HIV infection, chronic kidney disease, tubulointerstitial lesions, glomerular kidney lesions.

Relevance. One of the most important problems of our time is the HIV epidemic. In the 30 -year history of this disease, HIV has affected more than 75 million people, of whom almost 30 million adults and children have died $[1,8]$. In the coming decades, the disease will continue to play a significant role in global premature mortality rates.

Kidney damage, which is often characterized by severe clinical manifestations, can significantly affect the prognosis of HIV-infected people [3]. Given the growing number of people living with HIV in the world and the increasing life expectancy of such patients, we should also expect an increase in the number of people living with HIV who need expensive kidney replacement therapy, as well as kidney transplants.

The world scientific literature highlights factors associated with kidney disease in HIV infection: history of kidney disease, uncontrolled HIV infection, time spent on HAART, old age, female gender, African descent (APOL1 genetic variant), CD4+-lymphocytes count $<200$ cells $/ \mathrm{ml}$, as well as the use of nephrotoxic drugs [5].
However, despite the large number of foreign publications devoted to this topic, the issue of kidney damage in HIV infection in Ukraine still remains insufficiently covered.

The objective of the work is to establish the clinical and laboratory features of kidney damage in HIV infection.

\section{MATERIALS AND METHODS}

We examined 292 HIV-infected patients who were under outpatient care at the Chernivtsi Regional Center for AIDS Prevention and Control.

In establishing the diagnosis, clinical and epidemiological data and the results of laboratory research methods were taken into account: serological and immunological (including determination of CD4+-lymphocytes). The initial examination of HIV-infected people was carried out when they were registered at the dispensary in accordance with CP № 580 dated 12.12.2003. The studies met the established standards of the Declaration of Helsinki, adopted in 1964 and revised by the 59th General Assembly of the Military Medical Academy, Seoul, October 2008. 
The mean age of all patients was $(29.3 \pm 8.2)$ years (range 19 to 55 years). Among the patients there were $188(64.4 \%)$ men and $104(35.6 \%)$ women. The study mainly included young patients (25-44 years).

Among the patients included in the study, the first clinical stage of HIV infection was detected in $26(8.9 \%)$, the second - in $40(13.7 \%)$, the third - in $108(37.0 \%)$ and the fourth clinical stage - in $118(40.4 \%)$ patients.

Correlation analysis of two quantitative traits was carried out by Spearman's ranking method: the relationship between the indicators was considered weak at $\mathrm{r}<0.3$, moderate - at $0.3<r<0.7$, strong - at $r>0.7$. Also statistical the significance of the obtained coefficient was evaluated using Student's t-test).

The amount of HIV in the blood of patients (viral load) was determined in the laboratory of the Ivano-Frankivsk Regional Municipal Center for AIDS Prevention and Control using test systems on equipment manufactured by Hoffman La Roche. The Amplicor HIV-1 MONITOR Test used polymerase chain reaction (PCR) technology to detect very little genetic material (RNA) contained in human immunodeficiency viruses. Virus concentration is described as the number of copies per milliliter of blood plasma (copies $/ \mathrm{ml}$ ). The level of viremia can range from 50 copies/ml to 20 million cop$\mathrm{ies} / \mathrm{ml}$ and above.

The results of recent studies [8] suggest that the concentration of HIV virus affects the degree of risk of disease progression. High levels of virus in the blood plasma ( $>100,000$ copies of RNA in $1 \mathrm{ml}$ of plasma) indicate rapid progression in AIDS, regardless of the number of CD4+ cells.

The study screened the markers of kidney damage (albuminuria/proteinuria) by test systems using urinary strips (AutionSticks-2EA). The results obtained with the help of test strips were considered as indicative. In the presence of $\geq 1+$ proteinuria in the screening test, which corresponded to a gradation of $30 \mathrm{mg} / 1$, repeated urine analyzes were performed with quantitative determination of protein on a MICROLAB-600 spectrophotometer using UNI-TEST-BM reagents, separated in time from 3 days to one week.

The functional state of the kidneys was assessed by an integrated indicator that characterizes the degree of preservation/loss of mass of active nephrons. The criterion for renal dysfunction was a decrease in glomerular filtration rate $(\mathrm{GFR})<60 \mathrm{ml} / \mathrm{min}$ by $1.73 \mathrm{~m} 2[7,9,10]$.

Chronic kidney disease was diagnosed when proteinuria or proteinuria was detected in combination with a decrease in GFR for 3 months or more.

A screening study to identify markers of kidney damage (persistent proteinuria, GFR in 3 months or more) in HIV-infected individuals was conducted in accordance with the recommendations of the National Kidney Foundation (Kidney Disease Outcome Quality Initiative, K/DOQI, 2002) and the American Associa- tion for Infectious Diseases Society of America, IDSA, $2005[2,4,9]$.

Among the examined patients there were 105 (36.0\%) persons with markers of renal damage - albuminuria/proteinuria. Based on the main markers of kidney damage - persistent proteinuria (PU) and GFR $<60 \mathrm{ml} / \mathrm{min} / 1.73$ $\mathrm{m} 2$ - in $16.4 \%$ of cases diagnosed with chronic kidney disease (CKD), which was often accompanied by impaired renal function.

HIV-associated nephropathy was found in 48 of 292 (16.4\%) patients (31 men, 17 women), in whom the examination revealed and confirmed markers of kidney damage - persistent proteinuria or proteinuria in combination with decreased GFR.

\section{RESULTS AND DISCUSSION}

48 HIV-infected individuals with renal impairment had the following characteristic clinical symptoms and CKD syndromes (Fig. 1):

- urinary syndrome, characterized by isolated proteinuria of various degrees, proteinuria in combination with hematuria/leukocyturia;

- arterial hypertension (AH);

- acute nephritic syndrome;

- nephrotic syndrome;

- chronic renal failure.

It was found that every fourth HIV-infected person with CKD had urinary syndrome with isolated PU (27.1\%). Most often PU was combined with changes in urinary sediment: erythrocyturia and leukocyturia (17 people $-35.4 \%$ ) or hematuria (14 patients $-29.2 \%$ ), and the latter was more often accompanied by $\mathrm{PU}>1.0 \mathrm{~g} /$ day, compared with the group of patients with lower levels of protein in the urine $(90.5$ and $51.9 \%$, respectively, $\mathrm{p}<0,01)$. In 4 patients $(8.3 \%)$ PU was combined with leukocyturia. It should be noted that more than half of the patients had transient bacterial leukocyturia - more often at $\mathrm{PU} \leq 1.0 \mathrm{~g} / \mathrm{day}$.

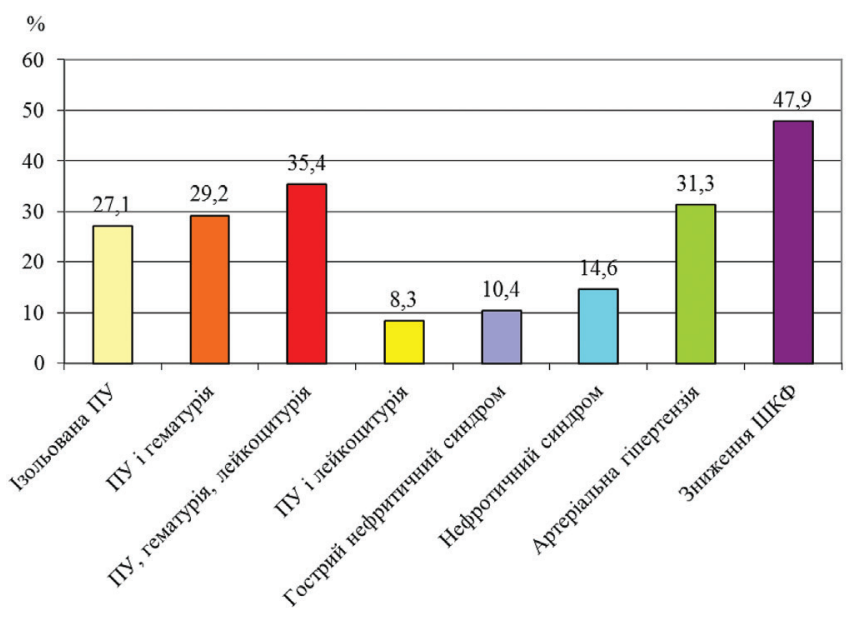

Fig. 1. Frequency of symptoms and syndromes of chronic kidney disease in HIV-infected $(\mathrm{n}=48)$ 
AH was diagnosed in 15 patients $(31.3 \%)$ in the presence of proteinuria compared with $2.5 \%$ in its absence $(\mathrm{p}<0.001)$. Acute nephritic syndrome was found in 5 patients $(10.4 \%)$, nephrotic syndrome - in 7 (14.6\%), decreased GFR $<60 \mathrm{ml} / \mathrm{min} / 1.73 \mathrm{~m} 2$ - in 23 people $(47.9 \%)$

Based on the analysis of complaints, anamnestic data and clinical symptoms of kidney damage, patients were divided into 2 groups. The first group consisted of 31 $(64.6 \%)$ with tubulointerstitial diseases, the second -17 (35.4\%) patients with glomerular diseases. As can be seen from the above data, in HIV-infected kidney damage is most often characterized by tubulointerstitial lesions.

Chronic tubulointerstitial kidney disease was characterized by minimal or insignificant PU $(0.4[0.3 ; 0.8]$ $\mathrm{g}$ /day) (median [interquartile range]), and only in 4 $(12.9 \pm 6.0) \%$ of patients it exceeded $1 \mathrm{~g} /$ day. Isolated PU was observed in $9(29.0 \pm 8.1) \%$ of cases, but in most individuals PU was combined with changes in urine sediment. Thus, PU was accompanied by hematuria, represented by isomorphic erythrocytes, and leukocyturia in $8(25.8 \pm 7.9) \%$ of patients, hematuria - in $2(6.5 \pm 4.4) \%$ and leukocyturia - in $4(12.9 \pm 6.0) \%$ of patients.

In tubulointerstitial diseases compared with glomerular renal pathology, renal dysfunction was significantly less frequently recorded $(32.3 \pm 8.4 \%$ versus $76.5 \pm 10.3 \%$, $\mathrm{p}<0.01)$; also $\mathrm{AH}(9.7 \pm 5.3 \%$ and $70.6 \pm 11.0 \%$ respectively, $\mathrm{p}<0.001)$.

Glomerular kidney damage was characterized by a significantly lower glomerular filtration rate - 48.7 [30.2; $78.9]$ versus $84.5[52.6 ; 107.2] \mathrm{ml} / \mathrm{min} / 1.73 \mathrm{~m} 2(\mathrm{p}<0.05)$. Accordingly, only 1 person with glomerular lesion GFR exceeded $90 \mathrm{ml} / \mathrm{min} / 1.73 \mathrm{~m} 2$, which was sharply inferior to the corresponding frequency of this symptom in tubulointerstitial pathology $(48.4 \pm 9.0 \%, \mathrm{p}<0.001)$. The final stage of CKD occurred in three $(17.6 \pm 9.2) \%$ of patients, two of whom recommended renal replacement therapy with programmed hemodialysis.

At glomerular damage of kidneys noted also essentially higher level of PU $(1,3[1,4 ; 3.0]$ vs. 0.4 [0.3; 0.8$]$ $\mathrm{g} /$ day, $\mathrm{p}<0.05)$. In 8 patients it exceeded $3.0 \mathrm{~g} / \mathrm{day}$, and in two of them it reached 8.0 and $9.0 \mathrm{~g} /$ day. Significantly more often than in patients with tubulointerstitial diseases found a combination of PU with hematuria $(64.7 \pm 11.6 \%$ vs. $6.5 \pm 4.4 \%, \mathrm{p}<0.001)$; with hematuria and aseptic leukocyturia $(52.9 \pm 12.1$ vs. $25.8 \pm 7.9 \%$, respectively, $\mathrm{p}<0.05)$. In most cases, microhematuria represented by dysmorphic erythrocytes was noted, while episodic macrohematuria was observed in two patients.

$7(41.2 \pm 11.9 \%)$ of patients were diagnosed with nephrotic and $5(29.4 \pm 11.0 \%)$ with acute nephritic syndromes. It is noteworthy that these syndromes are not found in any member of the group with tubulointerstitial disease. As expected, the level of hemoglobin in glomerular kidney damage was significantly lower (99.1 [83.0; 123.6] versus 124.0 [112.5; 133.0] g/l, p <0.05).
In patients with glomerular kidney disease, compared with tubulointerstitial diseases, significantly higher levels of HIV RNA were determined (Fig. 2).

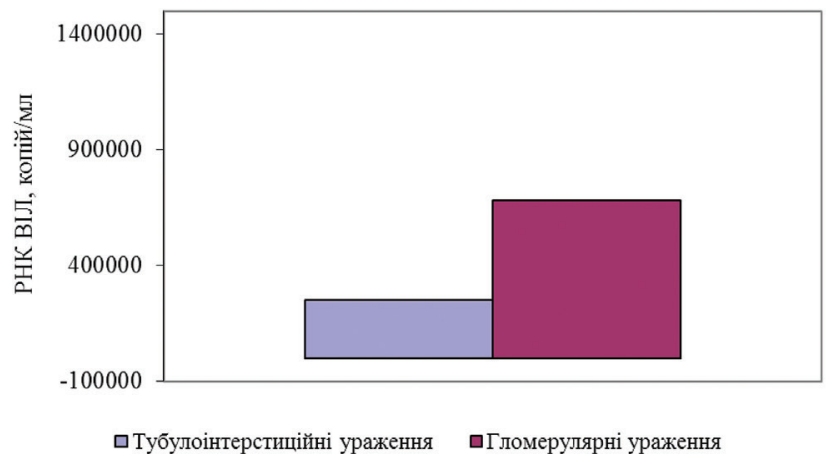

Fig. 2. HIV RNA levels in patients with different variants of kidney damage

This may indicate a direct effect of HIV on the glomerular apparatus, whereas tubulointerstitial kidney damage is most likely due to exposure to opportunistic infections and drugs with nephrotoxic potential, as well as the use of psychotropic drugs and uncontrolled use of nonsteroidal anti-inflammatory drugs.

The average number of CD4+ lymphocytes in the serum of patients with proteinuria is significantly less than in HIV-infected individuals without markers of kidney damage (185.5 [25\% - 60.9; 75\% - 318.0] against 312.0 [25\% $-175.5 ; 75 \%-469.0]$ cells/ $\mu$, respectively, $\mathrm{p}<0,05)$. Decreased levels of CD4+-lymphocytes $\leq 200 \mathrm{cells} / \mu \mathrm{l}$ were found in $52.1 \pm 7.2 \%$ of patients with proteinuria and in $30.0 \pm 7.2 \%$ in its absence $(p<0.05)$. Significantly significant is the difference between the values of the ratio of CD4+/CD8+ lymphocytes in the analyzed groups $(0.2$ $[0.1 ; 0.4]$ and $0.4[0.2 ; 0.6]$, respectively, $\mathrm{p}<0.05)$.

There were no significant differences in other indicators that characterize the course of HIV infection in people with different clinical variants of chronic kidney disease.

From this we can also conclude that the clinical manifestations of kidney damage in the studied patients coincide with those characteristic of certain variants of pathology in the general population of nephrological patients.

Numerous studies have been conducted worldwide to study the spectrum of kidney disease in HIV-infected individuals $[6,8,11]$. Thus, in studies conducted in the United States, it was found that, according to kidney biopsy, $52.7 \%$ of patients with PU nephrotic level were diagnosed with HIV-associated nephropathy. They were all African Americans. The high prevalence of this pathology is associated with racial affiliation, as well as with a special variant of the antigen / receptor for Duffytype chemokines, which is found in renal tissue $[4,5]$. According to multicenter studies conducted in France and Italy, where the majority of patients were Caucasian, immunocomplex lesions predominated among morpho- 
logically confirmed diagnoses in HIV-infected patients with renal pathology $[6,11]$.

It is known that one of the defining laboratory criteria for CKD is proteinuria. Therefore, the next stage of the work was to establish the clinical and laboratory features of renal dysfunction depending on the level of protein in the urine.

Depending on the level of proteinuria, patients were divided into two groups. The first group consisted of 27 of $48(56.3 \%)$ people with PU less than $1.0 \mathrm{~g} / \mathrm{day}$, the second group $-21(43.7 \%)$ patients with PU more than $1.0 \mathrm{~g} / \mathrm{day}$, in 7 of which it reached nephrotic level - more than $3.0 \mathrm{~g} /$ day.

Both groups were dominated by men $(70.4 \pm 8.4 \%$ and $57.1 \pm 10.9 \%$ respectively) and persons aged $25-44$ years $(66.7 \pm 9.1 \%$ and $61.9 \pm 10.6 \%$ respectively), as in the general population of HIV-infected.

Patients with HIV infection with a PU level of more than $1 \mathrm{~g}$ /day were significantly more often diagnosed with hypertension than in patients in whom proteinuria did not exceed this level $(52.4 \pm 10.9$ vs. $14.8 \pm 6.8 \%$, $\mathrm{p}<0.01)$. Thus, an association was established between PU levels and the presence of hypertension. It should be noted that the level of blood pressure patients in the groups were distributed as follows: Grade I hypertension was diagnosed in $3(11.1 \%)$ persons of the first and 3 $(14.3 \%)$ of the second group; Grade II hypertension was detected in $2(7.4 \%)$ and $4(19.0 \%)$ patients, respectively; Grade III hypertension occurred in only one $(3.7 \%)$ of the first group and in $3(14 \%)$ of patients with proteinuria $>1 \mathrm{~g} /$ day.

We found statistically significant intergroup differences in the severity of kidney damage depending on the level of proteinuria. Thus, preserved renal function (GFR $\geq 90 \mathrm{ml} / \mathrm{min} / 1.73 \mathrm{~m} 2$ ) was more often recorded in patients of group $1(48.1 \pm 9.6 \%)$ and significantly less often in individuals with proteinuria $>1 \mathrm{~g} /$ day, $5 \pm 6.4 \%$ ), $\mathrm{p}<0.01$. Conversely, GFR corresponding to stage 3 CKD was recorded in half $(47.6 \pm 10.9 \%)$ of patients with proteinuria $>1 \mathrm{~g}$ /day and only in $18.5 \pm 7.5 \%$ of patients with PU (1 g/day (Fig. 3). Accordingly, end-stage renal disease (GFR $<15 \mathrm{ml} / \mathrm{min} / 1.73 \mathrm{~m} 2$ ) was detected only in

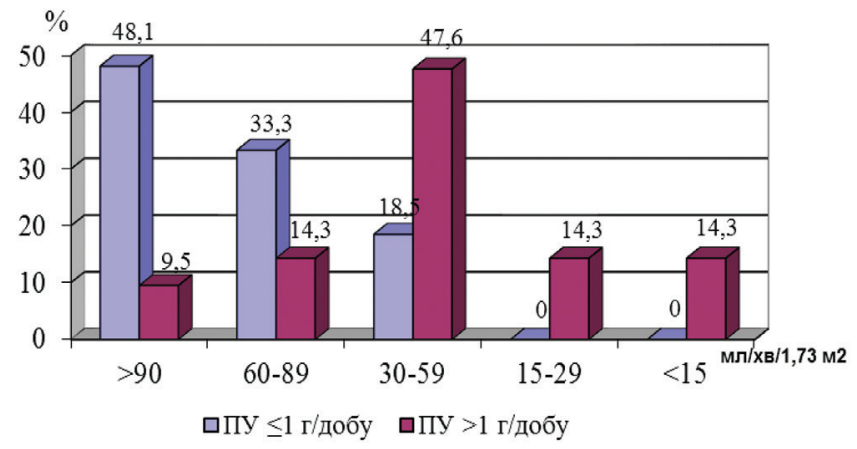

Fig. 3. Characteristics of the staged distribution of CKD in HIV-infected people with different levels of proteinuria patients of the second group, in 2 of whom the level of proteinuria exceeded $3.0 \mathrm{~g} /$ day.

Established an inverse medium-strength correlation between proteinuria levels and glomerular filtration rate $-(\mathrm{r}=-0.562, \mathrm{p}<0.01)$ (Fig. 4).

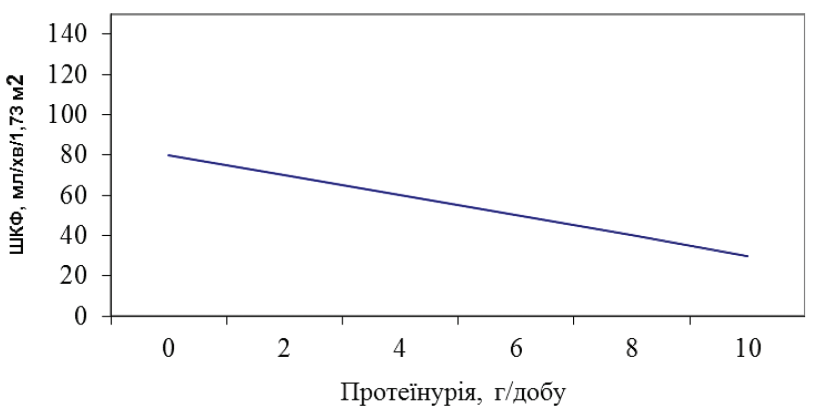

Fig. 4. Relationship between proteinuria levels and glomerular filtration rate

Thus, it was found that the increase in PU levels is accompanied by statistically significant renal impairment and more frequent combination with hypertension and hematuria in the absence of significant differences in the frequency of opportunistic diseases.

\section{CONCLUSIONS}

1. In HIV-infected kidney damage is most often characterized by their tubulointerstitial lesions. At the same time, glomerular kidney damage, which is much less common, is accompanied by significantly higher levels of HIV RNA.

2. An increase in the level of PU is accompanied by a significantly significant impairment of renal function and, more often, by a combination of arterial hypertension and hematuria in the absence of significant differences in the incidence of opportunistic diseases.

\section{REFERENCES}

1. Cohen S.D., Kopp J.B., Kimmel P.L. Kidney diseases associated with human immunodeficiency virus infection. New England Journal of Medicine. 2017; 377(24): 2363-74. DOI: 10.1056/NEJMra1508467

View at: Publisher Site: https://www.nejm.org/ doi/10.1056/NEJMra1508467

PubMed: https://pubmed.ncbi.nlm.nih.gov/29236630/

2. Cristelli M.P., Cofán F., Rico N., Trullàs J.C., Manzardo C., Agüero F., Miro J.M. Estimation of renal function by CKD-EPI versus MDRD in a cohort of HIV-infected patients: a cross-sectional analysis. BMC nephrology. 2017; 18(1): 1-7. doi: 10.1186/s12882-017-0470-4. View at: Publisher Site: https://bmcnephrol.biomedcentral.com/articles/10.1186/s12882-017-0470-4

PubMed: https://pubmed.ncbi.nlm.nih.gov/28183270/ PubMed Central: https:/www.ncbi.nlm.nih.gov/pmc/ articles/PMC5301369/

3. Eisinger R.W., Dieffenbach C.W., Fauci A.S. HIV viral 
load and transmissibility of HIV infection: undetectable equals untransmittable. Jama. 2019; 321(5): 451-2. doi: 10.1001/jama.2018.21167.

View at: Publisher Site: https://jamanetwork.com/ journals/jama/article-abstract/2720997

PubMed: https://pubmed.ncbi.nlm.nih.gov/30629090/

4. Ellis C.L. HIV associated kidney diseases: Clarifying concordance between renal failure in HIV infection and histopathologic manifestations at kidney biopsy. Seminars in diagnostic pathology. 2017; 34(4): 377-83. doi: 10.1053/j.semdp.2017.04.009

View at: Scopus: https://www.sciencedirect.com/science/article/abs/pii/ S0740257017300540?via\%3Dihub

PubMed: https://pubmed.ncbi.nlm.nih.gov/28578979/

Europe PMC: https://europepmc.org/article/ med/28578979

5. Frigati L., Mahtab S., Nourse P., Ray P., Perrazzo S., Machemedze T., Zar H. Prevalence of risk factors for chronic kidney disease in South African youth with perinatally acquired HIV. Pediatric Nephrology. 2019; 34(2): 313-8. doi: 10.1007/s00467-018-4080-6.

View at: Scopus: https://link.springer.com/ article/10.1007/s00467-018-4080-6

PubMed: https://pubmed.ncbi.nlm.nih.gov/30219929/

PubMed Central: https://www.ncbi.nlm.nih.gov/pmc/ articles/PMC6529608/

6. Jotwani V., Atta M.G., Estrella M.M. Kidney disease in HIV: moving beyond HIV-associated nephropathy. Journal of the American Society of Nephrology. 2017; 28(11): 3142-54. doi: 10.1681/ASN.2017040468 View at: Publisher Site: https://jasn.asnjournals.org/ content $/ 28 / 11 / 3142$

PubMed: https://pubmed.ncbi.nlm.nih.gov/28784698/ PubMed Central: https:/www.ncbi.nlm.nih.gov/pmc/ articles/PMC5661296/

7. Pokrovskiy V.V., Urin O.G., Kravchenko A.V. [National guidelines for dispensary observation and treatment of patients with HIV infection. Clinical Protocol]. Epidemiology and Infectious Diseases. The Actual Issues.
2017; 6(attachment):5-80 [in Russian].

View at: Publisher Site: https://epidemiology-journal. $\mathrm{ru} / \mathrm{ru} /$ archive/edition/9844

8. Saag M.S., Benson C.A., Gandhi R.T., Hoy J.F., Landovitz R.J., Mugavero M.J., ... \& Volberding P.A. Antiretroviral drugs for treatment and prevention of HIV infection in adults: 2018 recommendations of the International Antiviral Society-USA Panel. Jama. 2018; 320(4): 379-96. doi: 10.1001/jama.2018.8431

View at: Publisher Site: https://jamanetwork.com/ journals/jama/article-abstract/2688574

PubMed: https://pubmed.ncbi.nlm.nih.gov/30043070/ PubMed Central: https://www.ncbi.nlm.nih.gov/pmc/ articles/PMC6415748/

9. Shylov E.M. [Nefrology]. Moscow: GEOTAR-Media, 2010. 696 p. [in Russian].

View at: URL: https://www.rosmedlib.ru/book/ ISBN9785970416419.html

10. Swanepoel C.R., Atta M.G., D’Agati V.D., Estrella M.M., Fogo A.B., Naicker S., Zeier M. Kidney disease in the setting of HIV infection: conclusions from a Kidney Disease: Improving Global Outcomes (KDIGO) Controversies Conference. Kidney international. 2018; 93(3): 545-59. doi: 10.1016/j.kint.2017.11.007 View at: Publisher Site: https://www.kidney-international.org/article/S0085-2538(17)30823-2/fulltext PubMed: https://pubmed.ncbi.nlm.nih.gov/29398134/ PubMed Central: https://www.ncbi.nlm.nih.gov/pmc/ articles/PMC5983378/

11. Wyatt C.M. Kidney disease and HIV infection. Topics in antiviral medicine. 2017; 25(1): 13-6.

View at:PubMed: https://pubmed.ncbi.nlm.nih. gov/28402929/

PubMed Central: https://www.ncbi.nlm.nih.gov/pmc/ articles/PMC5677039/

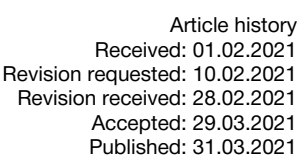

\title{
ОСОБЛИВОСТІ УРАЖЕНЬ НИРОК У ВІЛ-ІНФІКОВАНИХ ХВОРИХ
}

\author{
Москалюк В.Д., Андрущак М.О., Соколенко М.О., Баланюк І.В., Бойко Ю.І. \\ Буковинський державний медичний університет, Чернівиі, Україна \\ margaritaassistent@gmail.com
}

\begin{abstract}
Актуальність. У ВІЛ-інфікованих пацієнтів ураження нирок, яке характеризується тяжкими клінічними проявами, може істотно впливати на прогноз життя. Враховуючи зростання числа ВІЛ-інфікованих у світі та збільшення тривалості життя таких хворих, слід чекати й збільшення кількості ВІЛ-інфікованих осіб, які потребують дороговартісної замісної ниркової терапії, а також трансплантації нирки. Але питання характеру ураження нирок при ВІЛ-інфекції в Україні досі залишається недостатньо висвітленим.

Ціль: встановити клінічні та лабораторні особливості ураження нирок при ВІЛ-інфекції.

Матеріали і методи. Обстежено 292 хворих на ВІЛ-інфекцію. Здійснювали скринінг маркерів пошкодження нирок - альбумінурії/протеїнурії - тест-системами за допомогою сечових смужок. Результати, отримані за допомогою тест-смужок, розглядали як орієнтовні. За наявності у скринінговому тесті протеїнурії $\geq 1+$, що відповідала градації 30 мг/л, здійснювали повторні
\end{abstract}


аналізи сечі з кількісним визначенням білка на спектрофотометрі, розділені в часі від 3 діб до одного тижня. Функціональний стан нирок оцінювали за інтегральним показником, що характеризує ступінь збереження/втрати маси діючих нефронів. Критерієм порушення функції нирок було зниження швидкості клубочкової фільтрації (ШКФ) <60 мл/хв на 1,73 м2. Хронічну хворобу нирок діагностували при виявленні протеїнурії або протеїнурії у поєднанні зі зниженням ШКФ протягом 3 і більше місяців.

Результати. На підставі основних маркерів пошкодження нирок - персистентної протеїнурії (ПУ) і швидкості клубочкової фільтрації < 60 мл/хв/1,73 м² - у 48 осіб діагностована хронічна хвороба нирок, яка з великою частотою супроводжувалася порушенням функції цих органів. На підставі аналізу скарг, анамнестичних відомостей та клінічних симптомів ураження нирок хворі були розділені на 2 групи. Перша група (n=31, або 64,6 \%) - пацієнти з тубулоінтерстиційними, друга група (n=17, або 35,4 \%) - пацієнти 3 гломерулярними захворюваннями. Підвищення рівня ПУ супроводжується достовірно значущим порушенням функції нирок і частішим поєднанням з артеріальною гіпертензією і гематурією за відсутності достовірних відмінностей у частоті опортуністичних захворювань. Встановили зворотну середньої сили кореляцію між рівнями протеїнурії і швидкістю клубочкової фільтрації - $(\mathrm{r}=-0,562, \mathrm{p}<0,01)$, а також між рівнями протеїнурії та гемоглобіну $(\mathrm{r}=-0,596, \mathrm{p}<0,01)$.

Висновки. У ВІЛ-інфікованих ураження нирок найчастіше характеризується їх тубулоінтерстиційним ураженням. Водночас гломерулярне ураження нирок, що буває значно рідше, супроводжується достовірно вищим рівнем РНК ВІЛ.

Ключові слова: ВІЛ-інфекція, хронічна хвороба нирок, тубулоінтерстиційне ураження, гломерулярне ураження нирок.

\title{
ОСОБЕННОСТИ ПОРАЖЕНИЯ ПОЧЕК У ВИЧ-ИНФИЦИРОВАННЫХ БОЛЬНЫХ
}

\author{
Москалюк В.Д., Андрущцак Н.А., Соколенко Н.А., Баланюк И.В., Бойко Ю.И. \\ Буковинский государственный медицинский университет, Черновцьы, Украина \\ margaritaassistent@gmail.com
}

\begin{abstract}
Актуальность. У ВИЧ-инфицированных пациентов поражение почек, которое характеризуется тяжелыми клиническими проявлениями, может существенно влиять на прогноз жизни. Учитывая рост числа ВИЧ-инфицированных в мире и увеличение продолжительности жизни таких больных, следует ожидать и увеличения количества ВИЧ-инфицированных лиц, нуждающихся в дорогостоящей заместительной почечной терапии, а также трансплантации почки. Но вопрос характера поражения почек при ВИЧ-инфекции в Украине до сих пор остается недостаточно освещенным.
\end{abstract}

Цель: установить клинические и лабораторные особенности поражения почек при ВИЧ-инфекции.

Материалы и методы. Обследовано 292 больных ВИЧ-инфекцией. Осуществляли скрининг маркеров повреждения почек альбуминурии/протеинурии - тест-системами с помощью мочевых полосок. Результаты, полученные с помощью тест-полосок, рассматривали как ориентировочные. При наличии в скрининговом тесте протеинурии $\geq 1+$, которая соответствует градации 30 мг/л, осуществляли повторные анализы мочи с количественным определением белка на спектрофотометре, разделенные во времени от 3 дней до одной недели. Функциональное состояние почек оценивали по интегральному показателю, характеризующему степень сохранения/потери массы действующих нефронов. Критерием нарушения функции почек было снижение скорости клубочковой фильтрации (СКФ) $<60$ мл/мин на 1,73 м². Хроническую болезнь почек диагностировали при выявлении протеинурии или протеинурии в сочетании со снижением СКФ в течение 3 и более месяцев.

Результаты. На основании основных маркеров повреждения почек - персистентной протеинурии (ПУ) и скорости клубочковой фильтрации $<60$ мл/мин на 1,73 м2 - у 48 человек диагностирована хроническая болезнь почек, которая с большой частотой сопровождалась нарушением функции этих органов. На основании анализа жалоб, анамнестических сведений и клинических симптомов поражения почек больные были разделены на 2 группы. Первая группа (n=31, или 64,6\%) - пациенты с тубулоинтерстициальными, вторая группа ( $\mathrm{n}=17$, или $35,4 \%$ ) - пациенты с гломерулярными заболеваниями. Повышение уровня ПУ сопровождается достоверно значимым нарушением функции почек и более частым сочетанием с артериальной гипертензией и гематурией при отсутствии достоверных различий в частоте оппортунистических заболеваний. Установили обратную средней силы корреляцию между уровнями протеинурии и скоростью клубочковой фильтрации $-(\mathrm{r}=-0,562, \mathrm{p}<0,01), \mathrm{a}$ также между уровнями протеинурии и гемоглобина $(\mathrm{r}=-0,596, \mathrm{p}<0,01)$.

Выводы. У ВИЧ-инфицированных больных поражения почек чаще всего характеризуется их тубулоинтерстициальным поражением. Гломерулярное поражение почек бывает значительно реже, сопровождается достоверно более высоким уровнем РНК ВИЧ.

Ключевые слова: ВИЧ-инфекция, хроническая болезнь почек, тубулоинтерстициальное поражение, гломерулярное поражение почек. 